\title{
Profil content scale minnesota multiphasic personality inventory-2 (MMPI-2) adaptasi Indonesia pada komunitas "punk" di kawasan Megamas Manado
}

\author{
${ }^{1}$ Lavenia E. Mokiwang \\ ${ }^{2}$ Anita Dundu \\ ${ }^{2}$ Bernabas H. R. Kairupan \\ ${ }^{1}$ Kandidat Skripsi Fakultas Kedokteran Universitas Sam Ratulangi Manado \\ ${ }^{2}$ Bagian Psikiatri Fakultas Kedokteran, Universitas Sam Ratulangi Manado \\ Email: laveniamokiwang@ymail.com
}

\begin{abstract}
Punk" community is already scattered around the world, including Indonesia. The "punk" community is popular with their unique styles such as ripped jeans, sassy ear pin, necklace and bracelet, as well as spike-top and Mohican hair style. Music is also included in the "punk" community unique style because the music they created was a part of a rebellion, therefore, the lyrics are often without simile. The appearance and the unique styles of the "punk" community often result in negative specullation of the society towards them which can cause impact to the mental and personality of the "punk" community members. This was a cross-sectional survey study to obtain the personality and the mental status of the "punk" community members by using Content Scale MMPI-2 Indonesia Adaptation. Data were univariate analyzed using Microsoft Excel. The results showed that from 33 people who did the test, only 30 people were valid and their socio demographic data showed that the highest frequency was male $(86.67 \%)$. Score distribution of content scale MMPI-2 from the highest to the lowest was as foolows: BIZ (83.33\%), DEP (73.33\%), FAM (73.33\%), TRT (73.33\%), FRS (70\%), LSE (70\%), HEA (63.33\%), WRK (60\%), ANX (56.67\%), OBS (56.67\%), ASP (53.33\%), ANG (33.33)\%, CYN (33.33\%), TPA (16.67\%), and SOD $(3.33 \%)$.
\end{abstract}

Keywords: "punk" community, profile, content scale, MMPI-2

\begin{abstract}
Abstrak: Komunitas "punk" saat ini sudah tersebar di dunia, termasuk Indonesia. Komunitas "punk" terkenal dengan gayanya yang khas yaitu celana jeans yang sobek-sobek, peniti centil di telinga, kalung dan gelang serta gaya rambut spike-top dan Mohican. Musik juga termasuk dalam gaya khas komunitas "punk" karena musik yang mereka ciptakan ialah bagian dari pemberontakan sehingga tak jarang lirik dari musiknya juga tidak diberi kiasan. Penampilan dan gaya khas dari komunitas "punk" seringkali menimbulkan pemikiran negatif dari masyarakat yang bisa berdampak pada mental dan kepribadian dari anggota komunitas "punk". Jenis penelitian ialah survei potong lintang untuk mengetahui kepribadian dan mental anggota komunitas "punk" dengan menggunakan skala content scale MMPI-2 Adaptasi Indonesia. Data dianalisis secara univariat dengan menggunakan Microsoft Excel. Hasil penelitian memperlihatkan bahwa dari 33 orang yang mengikuti tes hanya 30 orang yang dinyatakan valid dan data sosio demografi menunjukkan frekuensi jenis kelamin lakilaki yang terbanyak $(86,67 \%)$. Distribusi skor tinggi Content Scale MMPI-2 berturut-turut dari yang paling tinggi ke rendah yaitu BIZ (83.33\%), DEP (73.33\%), FAM (73.33\%), TRT (73.33\%), FRS (70\%), LSE (70\%), HEA (63.33\%), WRK (60\%), ANX (56.67\%), OBS (56.67\%), ASP (53.33\%), ANG (33.33)\%, CYN (33.33\%), TPA (16.67\%), dan SOD $(3.33 \%)$.
\end{abstract}

Kata kunci: komunitas "punk", profil, content scale, MMPI-2 
Dalam perkembangan zaman saat ini, telah berdiri berbagai komunitas salah satunya komunitas "punk". Komunitas "punk" saat ini sudah banyak ditemui di seluruh dunia, termasuk Indonesia. Komunitas "punk" di Indonesia sudah tersebar di berbagai daerah seperti Jakarta, Bandung, Aceh, dan Makasar. " Komunitas "punk" juga sudah ditemukan di Manado meskipun anggotanya tidak sebanyak seperti di daerah lain. Komunitas "punk" biasanya mensosialisasikan diri mereka dengan cara yang berbeda salah satunya adalah musik. Musik yang mereka mainkan sangat keras, dan lirik di dalam lagu atau musik tersebut merupakan bentuk pemberontakan mereka yang tidak mereka berikan kiasan. ${ }^{2}$ Penampilan serta selera fashion komunitas "punk" juga sangat khas yaitu celana jeans sobek-sobek, peniti cantel di telinga mereka, aksesoris seperti kalung dan gelang. Gaya rambutnya juga khas seperti spike-top dan Mohican, sering dicat warnawarni. Komiunitas "punk" menyebut diri mereka antifashion. ${ }^{3}$ Penampilan seperti ini menimbulkan suatu pemikiran yang negatif dari masyarakat. Kepribadian komunitas "punk" seringkali membuat orang di sekitar salah menilai akan diri atau status mereka sebagai komunitas "punk".

Penelitian ini bertujuan mendapatkan kepribadian dan kesehatan mental serta keadaan sosio demografik pada komunitas "punk" dengan menggunakan MMPI-2. Minnesota Multiphasic Personality Inventory (MMPI) yaitu inventarisasi yang dilaporkan oleh pasien sendiri (self-report) yang paling luas digunakan dan instrumen penilaian kepribadian objektif yang paling luas diteliti.

\section{METODE PENELITIAN}

Jenis penelitian yang dilakukan menggunakan desain potobng lintang dan dilaksanakan pada September 2016Oktober 2016. Pengambilan data menggunakan kuesioner sosio-demografik dan kuesioner MMPI-2 (adaptasi Indonesia $-\mathrm{HKH})$.

Kriteria inklusi ialah anggota komunitas "punk" yang berada di tempat saat penelitian berlangsung, anggota komunitas "punk" yang berusia $\geq 18$ tahun dan anggota komunitas "punk" yang bersedia menjadi responden.

Analisis yang digunakan ialah univariat dengan mendeskripsikan setiap variabel penelitian dalam frekuensi dan presentase yang di sajikan dalam bentuk tabel distribusi. Untuk data skala klinis diserahkan pada teman yang menggunakan profil supplementary scale sebagai penelitian. Untuk menganalisis data sosiodemografi dan data hasil interpertasi MMPI-2, digunakan program Microsoft Excel.

\section{HASIL PENELITIAN}

Penelitian dilakukan pada anggota komunitas "punk" di Kawasan Megamas Manado. Responden diambil dari populasi anggota komunitas "punk" yang berada di Kawasan Megamas Manado berjumlah 30 orang. Tabel 1 menunjukkan data distribusi frekuensi responden menurut jenis kelamin. Responden laki-laki lebih banyak dibanding dengan perempuan $(86,67 \%$ lakilaki dan $13,33 \%$ perempuan) (Tabel 1).

Tabel 1. Distribusi frekuensi menurut Jenis kelamin

\begin{tabular}{ccc}
\hline Jenis kelamin & Jumlah & Persentase \\
\hline Laki-laki & 26 & 86.67 \\
\hline Perempuan & 4 & 13.33 \\
\hline Total & 30 & 100 \\
\hline
\end{tabular}

Tabel 2 menunjukkan data distribusi frekuensi responden menurut umur. Dalam table tersebut menunjukkan umur 20-39 memiliki frekuensi tinggi $(83,33 \%)$, yang kedua pada umur 13-19 tahun (10\%) dan umur 40-64 tahun $(6,67 \%)$.

Tabel 2. Distribusi frekuensi menurut Umur

\begin{tabular}{ccc}
\hline Umur & Jumlah & Persentase \\
\hline $11-20$ & 6 & 20 \\
\hline $21-40$ & 22 & 73.33 \\
\hline $40-65$ & 2 & 6.67 \\
\hline Total & 30 & 100 \\
\hline
\end{tabular}

Tabel 3 menunjukkan distribusi frekuensi nilai $\mathrm{T}$ skor yang tinggi $(\geq 65)$ 
sebagai berikut: ANX 56,67\%; FRS 70\%; OBS 56,67\%; DEP 73,33\%; HEA 63,33\%; BIZ 83,33\%; ANG 33,33\%; CYN 33,33\%; ASP 53,33\%; TPA $16,67 \%$; LSE 70\%; SOD 3,33\%; FAM 73,33\%; WRK 60\%; TRT $73,33 \%$.

\begin{tabular}{|c|c|c|}
\hline Content Scale & & $(\%)$ \\
\hline \multicolumn{3}{|l|}{ Anxiety (ANX) } \\
\hline \multirow[t]{3}{*}{ T Score } & $<40$ & 3,33 \\
\hline & $40-65$ & 40 \\
\hline & $>65$ & 56,6 \\
\hline \multicolumn{3}{|l|}{ Fears (FRS) } \\
\hline \multirow[t]{3}{*}{ T score } & $<40$ & 0 \\
\hline & $40-65$ & 30 \\
\hline & $>65$ & 70 \\
\hline \multicolumn{3}{|l|}{ Obsessiveness (OBS) } \\
\hline \multirow[t]{3}{*}{ T Score } & $<40$ & 0 \\
\hline & $40-65$ & 43,33 \\
\hline & $>65$ & 56,67 \\
\hline \multicolumn{3}{|l|}{ Depression (DEP) } \\
\hline \multirow[t]{3}{*}{ T Score } & $<40$ & 0 \\
\hline & $40-65$ & 26,67 \\
\hline & $>65$ & 73,33 \\
\hline
\end{tabular}

\begin{tabular}{|c|c|c|}
\hline $\begin{array}{c}\text { Health Concern } \\
\text { ( HEA) }\end{array}$ & & \\
\hline \multirow[t]{3}{*}{ T Score } & $<40$ & 3,33 \\
\hline & $40-65$ & 33,33 \\
\hline & $>65$ & 63,33 \\
\hline \multicolumn{3}{|c|}{ Bizzare Mentation (BIZ) } \\
\hline \multirow[t]{3}{*}{ T Score } & $<40$ & 0 \\
\hline & $40-65$ & 16,67 \\
\hline & $>65$ & 83,33 \\
\hline \multicolumn{3}{|l|}{ Anger (ANG) } \\
\hline \multirow[t]{3}{*}{ T Score } & $<40$ & 3,33 \\
\hline & $40-65$ & 63,33 \\
\hline & $>65$ & 33,33 \\
\hline \multicolumn{3}{|l|}{ Cynisme (CYN ) } \\
\hline \multirow[t]{3}{*}{ T Score } & $<40$ & 0 \\
\hline & $40-65$ & 66,67 \\
\hline & $>65$ & 33,33 \\
\hline
\end{tabular}

\begin{tabular}{|c|c|c|}
\hline $\begin{array}{l}\text { Antisocial Practices } \\
\text { (ASP) }\end{array}$ & & \\
\hline \multirow[t]{3}{*}{ T Score } & $<40$ & 0 \\
\hline & $40-65$ & 46,67 \\
\hline & $>65$ & 53,33 \\
\hline \multicolumn{3}{|l|}{ Type A (TPA) } \\
\hline \multirow[t]{3}{*}{ T Score } & $<40$ & 3,33 \\
\hline & $40-65$ & 80 \\
\hline & $>65$ & 16,67 \\
\hline \multicolumn{3}{|l|}{ Low Self -esteem (LSE) } \\
\hline \multirow[t]{3}{*}{ T Score } & $<40$ & 0 \\
\hline & $40-65$ & 30 \\
\hline & $>65$ & 70 \\
\hline
\end{tabular}

\begin{tabular}{ccc}
\hline $\begin{array}{c}\text { Social Discomfort } \\
(\text { SOD })\end{array}$ & & \\
\hline T Score & $<40$ & 3,33 \\
\hline
\end{tabular}

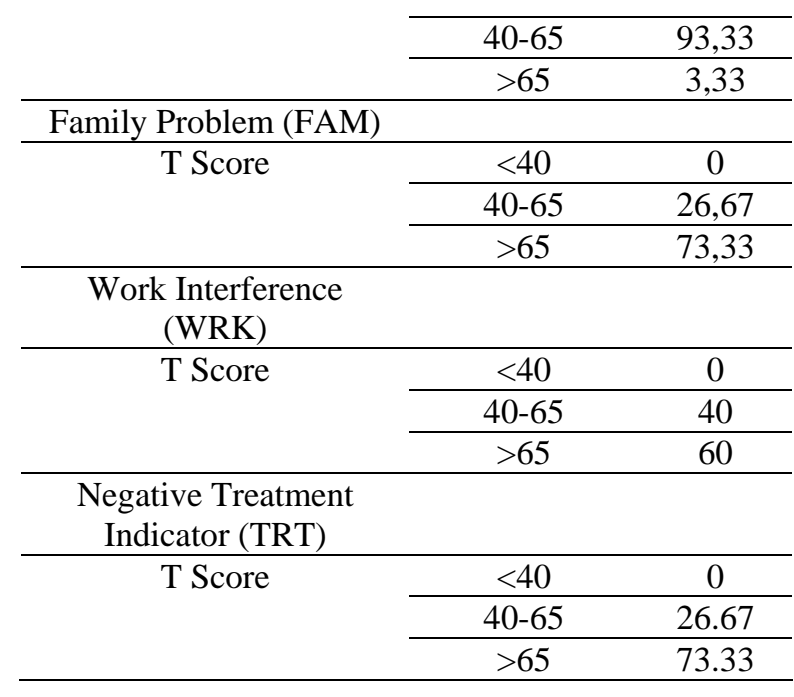

\section{BAHASAN}

Pada karakteristik Content Scale Minnesota Multiphasic Personality Inventory-2 (MMPI-2) terdapat beberapa skala yang memiliki skor tinggi yaitu BIZ $(83,33 \%)$, DEP $(73,33 \%)$, FAM $(73,33 \%)$ dan $\operatorname{TRT}(73,33 \%)$

\section{Bizzare Mentation (BIZ)}

Skor tinggi pada skala ini mempunyai proses berpikir yang psikotik, sering berhalusinasi (auditori, visual, penciuman), keyakinan paranoid, pikiran-pikiran aneh, delusi. Sedangkan jika skor rendah artinya tidak terdapat gejala-gejala psikotik atau ide-ide yang aneh. Hasil penelitian menunjukkan 25 orang $(83,33 \%)$ memiliki skor tinggi (>65) pada skala BIZ.

\section{Depression (DEP)}

Pada skala ini jika seorang memiliki skor tinggi, maka itu menunjukkan orang tersebut sedang memiliki banyak pemikiran yang depresif, tidak tertarik dalam hidup, merasakan kekosongan, merasa telah melakukan dosa yang tak terampuni, mudah menangis, tidak bahagia, mungkin memiliki keinginan bunuh diri, perasaan bahwa orang lain tidak cukup mendukung, sensitif terhadap penolakan, tegang, perasaan pasif tentang keputusasaan, ketidakberdayaan terhadap masa depan. Sedangkan skor <40 menunjukkan orang tersebut tidak depresi. Hasil penelitian menunjukkan 22 orang $(73,33 \%)$ memiliki skor $>65$ pada skala DEP. 


\section{Family Problem (FAM)}

Skor tinggi menggambarkan terdapat perselisihan dalam keluarga, masa kecil tidak bahagia, pernikahan yang sulit dan tidak bahagia, keluarga yang dimiliki tidak banyak mengekspresikan cinta tetapi lebih banyak bertengkar dan tidak menyenangkan, mungkin mengalami tindak kekerasan di masa kecilnya. Pada skor rendah menunjukkan orang tersebut merasa didukung penuh oleh keluarga. Hasil penelitian ini menunjukkan 22 orang $(73,33 \%)$ memiliki skor tinggi pada skala FAM.

\section{Negative Treatment Indicator (TRT)}

Skor tinggi menunjukkan ketidaksukaan atau ketidakpercayaan untuk dibantu oleh profesional dalam bidang kesehatan, ketidaknyamanan dalam membahas kesulitannya, rendahnya tingkat keterbukaan diri, resisten terhadap perubahan, ketidakpercayaan pada kemungkinan perubahan, percaya bahwa tidak ada yang benar-benar dapat memahami atau membantu dirinya, cenderung untuk menyerah daripada menghadapi krisis. Jika seseorang memiliki skor rendah $(<40)$ maka orang tersebut percaya bahwa ia bisa mengatasi masalah.

\section{SIMPULAN}

Dari hasil penelitian ini dapat disimpulkan bahwa dari data sosiodemografik didominasi oleh laki-laki dan terbanyak pada kelompok umur 20-39 tahun. Pada hasil MMPI-2 Adaptasi Indonesia, didapatkan hasil content scale dengan $\mathrm{T}$ skor tinggi pada ANX, FRS, OBS, DEP, HEA, BIZ, ANG, CYN, ASP, TPA, LSE, SOD, FAM, WRK, dan TRT. Skala yang memiliki peninggian $\mathrm{T}$ Score $>65$ ialah BIZ, DEP, FAM dan TRT.

\section{SARAN}

Penelitian dengan menggunakan MMPI-2 Adaptasi Indonesia bisa dijadikan sebagai alat skrining untuk kepribadian dan status mental setiap orang. Perlu dilakukan penelitian lanjutan terhadap komunitas "punk" untuk mencari tahu faktor-faktor yang memengaruhi hasil-hasil dari skala content scale.

\section{DAFTAR PUSTAKA}

1. Maghfiroh T. Konsep Diri Anggota Komunitas Punk Malang [Skripsi]. Malang: Fakultas Psikologi Universitas Islam Negeri Malang; 2007.

2. Pickles JM. Dari Subkultur ke Budaya Perlawanan: Aspirasi dan Pemikiran Sebagian dari Kaum Punk/Hardcore dan Skinhead di Yogyakarta dan Bandung [Skripsi]. Program Acicis FISIP Universitas Muhammadiyah Malang; 2000.

3. Hebdige D. Subculture: The Meaning of Style. 2002. Diunduh dari www.isns.uw.edu.pl [15 April 2013].

4. Kaplan H, Sadock B,G Rebb J. Psikologi dan Psikiatri: Psikometri dan Tes Neuropsikologi. Sinopsis Psikiatri Ilmu Pengetahuan Perilaku Psikiatri Klinis Jilid 1. Jakarta: Binarupa Aksara Publisher, 2010; p. 352. 